Riga, Latvia, November 20, 2020

\title{
MODERN FEATURES OF EDUCATIONAL MOTIVATION ACTIVITY FOR ADULTS
}

\section{Violetta Ivanchenko ${ }^{1}$}

DOI: https://doi.org/10.30525/978-9934-26-002-5-40

Experience has shown that education helps individuals to improve their lives, to achieve a higher status, to be more active in economic, political and other fields. Modern technological information and communication technologies shows that people have to learn almost throughout their life. However, in Ukraine unlike in other countries, nowadays does not attach enough attention to the importance of adult education.

First of all, we need to take into account that the concept of adult learning is completely different from the education of children and teenagers [1; 2, p. 165]. The structure and forms of adult education should be adequate to their inquiries, and give them the option to choose subjects and forms of education [1]. (According to various sociological research [3, p. 206]).

Psychological principles of adult learning: workshops, seminars, master classes [3, p. 296]. Studing of their motives allows us to conclude that among them the main ones are: realization of their creative potential; the necessity to pass something to the next generation; the adjustment of activity in terms of possible stagnation and lost opportunities; concern for the safety of loved ones relationships with family and friends; preparation for a secure life in old age. In the context of these changes there will be a comprehension and reassessment of life in general; adjustment of the formed system of values in three interconnected areas: personal, family and professional.

The critical point of motivational crisis will be the loss of a personal life motivation in the meaning of life, the formation of an existential motivational vacuum, which is the cause of neurotic disorders that do not depend on gender, age, education, intelligence, income, which can happen with any person.

Basic life support needs help to overcome with self-actualization and selfrealization, which is the main motivational aspect of educational activities for this age.

Many middle-aged people are giving up further growth and prefer to think just about their security and safety, deliberately limit their motivational structure, narrowing the living space, mobility of behavior and doom themselves to the inertia of life and stagnation of themselves as individuals.

\footnotetext{
${ }^{1}$ Zaporizhzhya Polytechnic National University, Ukraine
} 
In addition, we pay attention to the fact that today there is inevitably need for retraining, searching or creating something new. Corporate academies and universities can help easily with acquire new skills, knowledge, change the way of thinking. Note what approaches and principles help in motivation. The first is relevance, a maximum of working knowledge and skills which now facilitate the work, increase efficiency. The second is quick success dopamine reinforcement from the fact that something I just learned quickly turns out, brings results in work. The third is an online stream. Stream from the workplace - an opportunity to show in practice something new, relevant, interesting - it is both a game of curiosity, the use of convenient for most people, a visual channel of information, and the ability to connect all those interested in self-development. Also an important principle - feedback in the learning process [4, p. 87].

And finally, in view of all the above, we can say that for achieving successful learning activities in an adult audience it is necessary to comprehensively explore and analyze the motives that motivate an adult to study, to clarify their needs, interests, attitudes and aptitudes, all of which significantly affects learning outcomes.

\section{References:}

1. Creighton S., Hudson L. Participation Trends and Patterns in Adult Education: 1991 to 1999: Statistical Analysis Report. February 2002. Available at: http: //nces.ed.gov/pubsearch/index/asp

2. Jucevičiene P. Lyginamoji edukologija (Comparative education). Kaunas: Technologija, 1997.

3. Klaus Fopel [Transl. from German M. Polyakov]. Moscow: Genesis, 2010. 359 p.

4. Lebedeva, N. V. (2014). Psychological mechanisms and features of motivation of educational activity of adults in the system of retraining and advanced training: monograph. Moscow: Pero, $187 \mathrm{p}$. 